\title{
HUBUNGAN MOTIVASI BELAJAR DAN HASIL BELAJAR RIAS WAJAH SEHARI-HARI DENGAN MINAT BERWIRAUSAHA SISWA TATA KECANTIKAN KULIT SMKNEGERI 1 BERINGIN
}

\author{
Isma Maisarah Rangkuti dan Siti Wahidah \\ (Pengusaha Galeri Make Up Isma dan Dosen Jurusan PKK)
}

\begin{abstract}
ABSTRAK
Penelitian ini bertujuan untuk mengetahui hubungan motivasi belajar dengan minat berwirausaha siswa tata kecantikan SMK N 1 Beringin.Untuk mengetahui hubungan hasil belajar rias wajah sehari-hari dengan minat berwirausaha siswa tata kecantikan SMK N 1 Beringin. Untuk mengetahui hubungan motivasi belajar dan hasil belajar Rias wajah sehari-hari dengan minat berwirausaha siswa tata kecantikan SMK N 1 Beringin. Teknik analisis data yang digunakan adalah analisis regresi ganda. Hasil penelitian diperoleh bahwa(1) Tingkat kecenderungan motivasi belajar siswa kelas X dan XI Tata Kecantikan SMK Negeri 1 Beringin yaitu sebanyak 88,33\%. (2) Tingkat kecenderungan hasil belajar siswa cenderung cukup yaitu sebanyak 75\%. (3) Tingkat kecenderungan minat berwirausaha siswa yaitu 65\%. (4) Terdapat hubungan yang signifikan antara motivasi belajar dengan minat berwirausaha pada siswa Tata Kecantikan SMK Negeri 1 Beringin. Hal ini dibuktikan dari nilai $t_{\text {hitung }}=3,265$ dan nilai $t_{\text {tabel }}=2,00$ dimana $t_{\text {hitung }}>t_{\text {tabel }}$. (5) Terdapat hubungan signifikan antara hasil belajar dengan minat berwirausaha pada siswa Tata Kecantikan SMK Negeri 1 Beringin. Hal ini dibuktikan dari nilai $t_{\text {hitung }}=2,734$ dan nilai $t_{\text {tabel }}=2,00$ dimana $t_{\text {hitung }}>t_{\text {tabel }}$. (6) Terdapat hubungan yang signifikan antara motivasi belajar dan hasil belajar dengan minat berwirausaha pada siswa kelas X dan XI Tata Kecantikan SMK Negeri 1 Beringin. Hal ini dibuktikan dari nilai $R=0.7898$ dan nilai $r_{\text {tabel }}=0.254$ dimana $R>r_{\text {tabel }}$. Uji signifikansi korelasi $\mathrm{R}$ diperoleh $F_{\text {hitung }}=47,252$ dimana $F_{\text {tabel }}=3,158$. Maka $F_{\text {hitung }}>F_{\text {tabel }}$ dapat disimpulkan Ho ditolak dan Ha diterima.
\end{abstract}

\section{Kata Kunci : Motivasi Belajar, Hasil Belajar}

\section{PENDAHULUAN}

Lembaga pendidikan (sekolah) merupakan wadah para siswa dalam menggali ilmupengetahuan, salah satu factor penting yang dapatmempengaruhi tingkat hasil belajar siswa adalah motivasi belajar yang adapada diri siswa. Adanya motivasi belajar yang kuat membuat siswa belajardengan tekun yang pada akhirnya terwujud dalam hasil belajar siswa tersebut, oleh karena itulah motivasi belajar hendaknya ditanamkan pada diri siswa agar dengan demikian siswaakan dengan senang hati akan mengikuti materipelajaran yang diajarkan oleh guru di sekolah. Perlu ditanamkan pada dirisiswa bahwa dengan belajarlah akan mendapatkan pengetahuan yang baik, siswa akan mempunyai bekal menjalani kehidupannya di kemudian hari.

Penyebab banyaknya pengangguran di Indonesia ialah karena jumlah tenaga kerja jauh lebih banyak dibandingkan dengan lapangan kerja yang tersedia. Melemahnya 
daya serap tenaga kerja di beberapa sektor industri, membuat angka pengangguran bertambah. Badan Pusat Statistik (BPS) melaporkan jumlah pengangguran di Indonesia pada Agustus 2015 sebanyak 7,56 juta orang, bertambah 320 ribu orang dibandingkan dengan periode yang sama tahun lalu 7,24 juta jiwa.Fenomena ini seharusnya dapat dijadikan bahan pemikiran, bagaimana dapat menciptakan lapangan kerja baru yang dapat menampung karyawan, tidak lagi berpikir untuk mempersiapkan diri menjadi calon karyawan yang mencari pekerjaan.

Sesuai dengan tujuan SMK N 1 Beringin tersebut maka siswa lulusan SMKN 1 Beringin akan dapat mengembangkan kemampuan lulusannya untuk dapat berkarir pada bidang-bidang keahliannya. SMKN 1 Beringin juga mampu menciptakan tenaga siap pakai, bekerja secara mandiri dengan bakat dan ketrampilan yang telah didapatkan selama dibangku sekolah. Tidak menutup kemungkinan lulusan sekolah menengah kejuruan dapat menciptakan lapangan pekerjaan baru (berwirausaha), menciptakan sesuatu yang baru dan bermanfaat bagi orang banyak.

\section{KAJIAN PUSTAKA}

Definisi Motivasi belajar menurut Ginting (2010) adalah "Sesuatu yang menggerakkan atau mendorong siswa untuk belajar atau menguasai materi pelajaran yang sedang diikutinya. "Dimyati dan Mudjiono (2009) mengemukakan definisi motivasi belajar sebagai "kekuatan mental yang mendorong terjadinya belajar atau dorongan mental yang menggerakkan dan mengarahkan perilaku manusia (perilaku belajar)."Jadi motivasi belajar merupakan motivasi (dorongan) internal dan eksternal siswa untuk belajar guna memperoleh prestasi yang baik.

Hasil belajar adalah sebuah kalimat yang terdiri dari dua kata yakni "Hasil" dan "Belajar".Hasil berarti sesuatu yang diadakan (dibuat, dijadikan, dsb) oleh usaha.Belajar adalah usaha memperoleh kepandaian atau ilmu.
Tata rias wajah merupakan salah satu ilmu yang mempelajari seni merias wajah untuk menampilkan kecantikan diri sendiri atau orang lain menggunakan kosmetika yang dapat menutupi atau menyamarkan kekurangan yang ada pada wajah, serta dapat menonjolkan kelebihan yang ada pada wajah sehingga tercapai kecantikan yang sempurna. Selain itu Tata rias merupakan seni menggunakan bahan-bahan kosmetika untuk mewujudkan wajah peranan (Gavinda. 2013).

Rias wajah bukan merupakan hal yang baru dilakukan ataupun baru dikenal, sejak ribuan tahun tahun yang lalu rias wajah sudah dikenal dan diterapkan oleh kaum wanita khususnya. Setiap Negara dan bangsa mempunyai ciri-ciri dan tanda-tanda ataupun standar tertentu akan arti cantik. (Azzurasantika, 2013).

Rias wajah adalah seni kecantikan diri sendiri ataupun orang lain dengan menggunakan kosmetik dengan cara menutupi ataupun menyamarkan bagianbagian wajah seperti hidung, mata, bibir, dan alis dengan warna bayangan yang gelap (shade) misalnya warna cokelat (Azzurasantika, 2013).

Tujuan merias wajah adalah untuk mempercantik diri pada umumnya, khususnya wajah, agar kelihatan segar dan cantik dan menambah rasa percaya diri. Untuk melakukan rias wajah pertama sekali memerlukan koreksi bentuk wajah dan bagian-bagian wajah seperti, mata, hidung, bibir, dagu dan alis, untuk melakukan suatu koreksi dipergunakan warna gelap atau terang (Azzurasantika, 2013).

Menurut Yanto, minat wirausaha adalah kemampuan untuk memberanikan diri dalam memenuhi kebutuhan hidup serta memecahkan permasalahan hidup, memajukan usaha atau menciptakan usaha baru dengan kekuatan yang ada pada diri sendiri. Hal yang paling utama yaitu sifat keberanian untuk menciptakan usaha baru. Menurut Santoso, minat wirausaha adalah gejala psikis untuk memusatkan perhatian dan berbuat sesuatu terhadap wirausaha itu dengan perasaan senang karena membawa manfaat bagi dirinya. Inti dari pendapattersebut adalah pemusatan perhatian yang disertai rasa senang. 
Dengan adanya perkembangan IPTEK sekarang ini, akan meningkatkan kebutuhan ekonomi masyarakat. Oleh karena itu, khususnya dunia pendidikan harus mampu berperan aktif menyiapkan sumberdaya manusia terdidik yang mampu menghadapi berbagai tantangan kehidupan. Siswa tidak cukup hanya menguasai teoriteori, tetapi juga mau dan mampu menerapkannya dalam kehidupan sosial. Siswa tidak hanya mampu menerapkan ilmu yang diperoleh di

bangku sekolah, tetapi juga mampu memecahkan berbagai persoalan yang dihadapi dalam kehidupan sehari-hari.

Motivasi akan menyebabkan suatu perubahan energi yang ada pada diri manusia, sehingga akan bergayut dengan persoalan gejala kejiwaan, perasaan dan juga emosi, untuk kemudian bertindak atau melakukan sesuatu. Semua ini didorong karena adanya tujuan, dorongan dan kebutuhan. Seseorang itu akan berhasil dalam belajar, kalau pada dirinya sendiri ada keinginan untuk belajar. Keinginan atau dorongan untuk belajar inilah yang disebut dengan motivasi. Demikian yang diharapkan dari para siswa, selain memiliki motivasi belajar yang tinggi dan hasil belajar yang berprestasi kemudian pada akhirnya diharapkan akan meningkatkan minat dalam berwirausaha.

Hipotesis merupakan jawaban sementara terhadap rumusan masalah penelitian, dimana rumusan masalah penelitian telah dinyatakan dalam bentuk kalimat pertanyaan.Dikatakan sementara, karena jawaban yang diberikan baru didasarkan pada teori yang relevan, belum didasarkan pada fakta-fakta empiris yang diperoleh melalui pengumpulan data.Jadi hipotesis juga dapat dinyatakan sebagai jawaban teoritis terhadap rumusan masalah penelitian, belum jawaban yang empirik dengan data (Sugiono, 2012).

Berdasarkan kerangka berfikir yang telah diuraikan diatas, maka dapat dikemukakan hipotesis yaitu :

$\mathrm{Ha}$ : Terdapat hubungan antara Motivasi Belajar dan Hasil Belajar Rias Wajah Sehari-hari dengan Minat berwirausaha Siswa Tata Kecantikan Kulit SMK Negeri 1 Beringin.

\section{METODOLOGI PENELITIAN}

Sesuai dengan tujuan hubungan motivasi belajar dan hasil belajar dengan minat berwirausaha siswa tata kecantikan SMK Negeri 1 Beringin maka penelitian ini merupakan penelitian deskriptif korelasional yaitu cara atau teknik yang mengungkapkan fakta yang jelas tentang gejala-gejala yang ada pada suatu objek penelitian (Notoatmojo,2010).

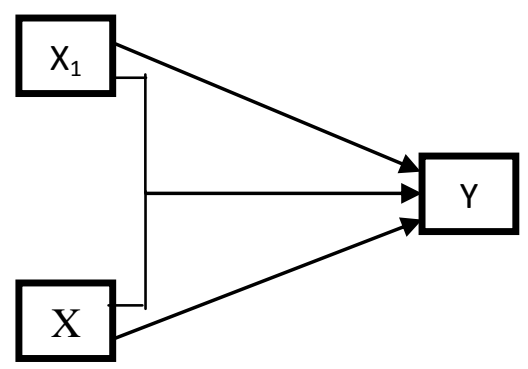

Penelitian ini dilaksanakan di SMK Negeri 1 Beringin. Waktu pelaksanaan penelitian akan dilaksanakan pada bulan Juni 2016.

Populasi dalam penelitian ini yakni siswa kelas X dan XI Tata Kecantikan SMK $\mathrm{N} 1$ Beringin, sebanyak 60 orang yang sedang mengikuti mata pelajaran rias wajah sehari-hari. Sampel adalah bagian dari jumlah dan karakter yang dimiliki dari populasi tersebut. Menurut Arikunto (2008), apabila subjek penelitian kurang dari 100 orang, lebih baik diambil semua. Penelitian ini menggunakan keseluruhan siswa kelas $\mathrm{X}$ dan XI Jurusan Tata Kecantikan Kulit SMK Negeri 1 Beringin dengan jumlah. Dengan demikian sampel penelitian ini adalah sampel populasi (60 orang) atau disebut total sampling.

Instrumen penelitian untuk mengumpulkan data tentang variable X1 diperoleh melalui angket yang disusun sendiri dengan menggunakan skala Likert yang dimodifikasi menjadi 4 pilihan jawaban. Setiap pernyataan yang disusun terdiri dari 4 pilihan jawaban, dimana setiap jawaban ditentukan bobot skornya sebagai berikut : 1) Sangat setuju (SS) $=4,2$ ) Setuju $(\mathrm{S})=3,3)$ Kurang setuju $(\mathrm{KS})=2,4)$ Tidak setuju $(\mathrm{TS})=1$ 
Menurut Arikunto, (2006) tes adalah serangkaian pertanyaan atau latihan yang digunakan untuk mengukur keterampilan pengetahuan, intelegensi, kemampuan dan bakat yang dimiliki oleh individu atau kelompok. Bentuk tes yang digunakan adalah pilihan beganda dengan jumlah soal 40 soal yang terdiri dari empat pilihan jawaban dari keempat pilihan tersebut, hanya terdapat satu jawaban yang benar dan pilihan lainnya merupakan jawaban pengecoh.

Instrumen penelitian untuk mengumpulkan data tentang variabel $\mathrm{Y}$ diperoleh melalui angket yang disusun sendiri dengan bentuk skala Likert yang dimodifikasi menjadi 4 pilihan. Setiap pernyataan yang disusun terdiri dari 4 pilihan jawaban, dimana setiap jawaban ditentukan bobot skornya sebagai berikut:

1) Sangat setuju $(S S)=4,2)$ Setuju $(S)=3$,

3) Kurang setuju $(\mathrm{KS})=2$, 4) Tidak setuju $(\mathrm{TS})=1$

Uji coba instrumen diadakan untuk mengetahui apakah instrument yang disusun dari setiap ubahan penelitian sudah valid dan reliabel. Instrumen dikatakan valid apabila mampu mengukur apa yang diinginkan, sedangkan reliabel menunjukkan bahwa suatu instrumen dapat dipercaya untuk digunakan sebagai alat pengumpul data (Arikunto, 2008). Uji coba dilaksanakan di sekolah SMK Negeri 1 Lubuk Pakam dengan alasan bahwa SMK Negeri 1 Beringin memiliki kesamaan dengan SMK Negeri 1 Lubuk Pakam.

Teknik analisis data adalah kegiatan mengelompokkan data berdasarkan variabel dan jenis responden, mendeskripsikan data, mencari tingkat kecenderungan variabel penelitian, menguji persyaratan analisis, menguji hipotesis.

\section{HASIL DAN PEMBAHASAN}

\section{Hasil Penelitian}

Pada bagian ini akan di deskripsikan hasil penelitian secara menyeluruh dari data yang diperoleh yaitu data motivasi belajar siswa, hasil belajar siswa dan minat berwirausaha siswa. Sampel peneitian berjumlah 60 orang siswayang berasal kelas
X dan XI Tata Kecantikan SMK Negeri 1 Beringin

\section{Pembahasan}

Berdasarkan hasil analisis data penelitian tingkat kecenderungan motivasi belajar pada siswa kelas X dan XI Tata Kecantikan SMK Negeri 1 Beringin hanya berada pada tingkat kecenderungan tinggi, cukup dan kurang. Tidak ada siswa yang memperoleh tingkat kecenderungan yang rendah. Dimana ratarata motivasi belajar siswa sebesar 115,8 jauh di atas rata-rata skor ideal sebesar 100 . Siswa yang memperoleh tingkat kecenderungan tinggi sebanyak 6,67 \%. Siswa yang memperoleh tingkat kecenderungan cukup sebanyak 88,33\%. Siswa yang memperoleh tingkat kecenderungan rendah sebanyak 5. Secara keseluruhan tingkat kecenderungan motivasi belajar siswa pada siswa kelas $\mathrm{X}$ dan XI Tata Kecantikan SMK Negeri 1 Beringin cenderung cukup.

Berdasarkan hasil analisis data penelitian tingkat kecenderungan hasil belajar pada siswa kelas X dan XI Tata Kecantikan SMK Negeri 1 Beringin hanya berada pada tingkat kecenderungan tinggi, cukup dan kurang. Tidak ada siswa yang memperoleh tingkat kecenderungan yang rendah. Dimana ratarata hasil belajar siswa sebesar 25,45 jauh di atas rata-rata skor ideal sebesar 20.

\section{KESIMPULAN}

Berdasarkan hasil penelitian dan pembahasan dapat diambil kesimpulan sebagai berikut : (1) Tingkat kecenderungan motivasi belajar siswa kelas X dan XI Tata Kecantikan SMK Negeri 1 Beringin cenderung cukup yaitu sebanyak $88,33 \%$. (2) Tingkat kecenderungan hasil belajar siswa kelas X dan XI Tata Kecantikan SMK Negeri 1 Beringin cenderung cukup yaitu sebanyak $75 \%$. (2) Tingkat kecenderungan minat berwirausaha siswa kelas $\mathrm{X}$ dan XI Tata Kecantikan SMK Negeri 1 Beringin cenderung cukup yaitu sebanyak 65\%. (3) Terdapat hubungan yang signifikan antara motivasi belajar dengan minat berwirausaha pada siswa kelas X dan XI Tata Kecantikan SMK Negeri 1 Beringin. Hal ini dibuktikan dari nilai $t_{\text {hitung }}=3,265$ dan nilai 
$t_{\text {tabel }}=2,00$ dimana $t_{\text {hitung }}>t_{\text {tabel }}$.

Terdapat hubungan yang signifikan antara hasil belajar dengan minat berwirausaha pada siswa kelas X dan XI Tata Kecantikan SMK Negeri 1 Beringin. Hal ini dibuktikan dari nilai $t_{\text {hitung }}=2,734$ dan nilai $t_{\text {tabel }}=2,00$ dimana $t_{\text {hitung }}>t_{\text {tabel }}$. $\quad$ (5) Terdapat hubungan yang signifikan antara motivasi belajar dan hasilbelajar dengan minat berwirausaha pada siswa kelas X dan XI Tata Kecantikan SMK Negeri 1 Beringin. Hal ini dibuktikan dari nilai $R=0.7898$ dan nilai $r_{\text {tabel }}=0.254$ dimana $R>r_{\text {tabel }}$. Uji signifikansi korelasi $\mathrm{R}$ diperoleh $F_{\text {hitung }}=47,252$ dimana $F_{\text {tabel }}=3,158$. Maka $F_{\text {hitung }}>F_{\text {tabel }}$

\section{DAFTAR PUSTAKA}

Alphafiani, Mineil dan M. Shohibul Kahfi. (2012). Penerapan Pembelajaran Kontekstual Melalui Strategi React Untuk Meningkatkan Motivasi Dan Hasil Belajar Siswa. Di http://jurnalonline.um.ac.id/

Aprilia, Ade. 2015, Every Day Make-up, Jl.Palmerah Barat 29-37. Jakarta : PT. Gramedia Pustaka Utama.

Andiyanto. 2015, The Make Over : PT. Gramedia Pustaka Utama

Arikunto, Suharsimi, 2008.Prosedur Penelitian. Jakarta: Rineka Cipta

Azzuransantika, umi. 2013, Perawatan Kulit Wajah, (blogspot.com)

Baharuddin dan Esa Nur Wahyuni, 2012.Teori Belajar dan Pembelajaran.Yogyakarta: Ar Ruz Media.

Dimyati dan Mudjiono. 2009. Belajar dan Pembelajaran.Jakarta: Rineka Cipta

Sutikno, sobry (2009). Belajar dan Pembelajaran, Prospect. Bandung.

Gavinda. 2013, Tata Rias, (blogspot.com)

Ginting .(2010). Esensi Praktis Belajar dan Pembelajaran.Jakarta : Humaniora

Gusnaldi. 2013, The Masterpiece Make-Up of Gusnaldi, Jl.Palmerah Barat 29-37. Jakarta : PT. Gramedia Pustaka Utama

Hasibuan, Malayu S.P. 2005. Organisasi dan Motivasi. Jakarta: Bumi Aksara
Kasmir. 2009. Kewirausahaan. Jakarta: Raja Grafido Persada

Mardiyatmo. 2006. Kewirausahaan. Surakarta: Yudhistira.

Notoatmodjo, 2010.Metode penelitian kesehatan.Jakarta : Rineka Cipta.

Purwanto, Ngalim. 2011. Psikologi Pendidikan. Bandung : Remaja Rosdakarya.

Purnomo, B.H. 2005.Membangun Semangat Kewirausahaan. Yogyakarta : Laksbang Pressindo.

Riadi, Muchlisin. $2016 \quad$ Psikologi Pendidikan(pendidikan.com)

Remania. 2014, Tutorial Make Up Cantik : Prima. Jakarta

Slameto.2013. Belajar dan Faktor Yang Mempengaruhinya, Jakarta: Rineka Cipta.

Sardiman, 2012.Interaksi dan Motivasi Belajar Mengajar. Jakarta: PT Rajawali Pers.

Sugiono (2012), Metode Penelitian Administrasi, Bandung: Alfabeta.

Yuwono, Susatyo, Partini. 2008. Pengaruh pelatihan kewirausahaan terhadap tumbuhnya minat berwirausaha. Jurnal penelitian Humaniora, Vol. 9, No. 2, Agustus 2008. 